Dr ALEKSANDAR ŽIVOTIĆ, vanredni profesor

Filozofski fakultet, Univerzitet u Beogradu

Beograd, Republika Srbija

aleksandar.zivotic@f.bg.ac.rs

originalan naučni rad

UDK: 94(497.1)"1941"(093.2)

primljeno: 26. februar 2019.

327(497.1:47)"1941"(093.2)

prihvaćeno: 22. maj 2019.

https://doi.org/10.29362/ist20veka.2019.2.ziv.105-120

\title{
SOVJETSKA DIPLOMATIJA O DOGAĐAJIMA 26/27. MARTA 1941. U JUGOSLAVIJI
}

APSTRAKT: U članku se na osnovu do sada nepoznatih dokumenata Arhiva spoljne politike Ruske Federacije i dela objavljenih izvora analizira način na koji je sovjetska diplomatija sagledavala reakcije srpskog društva $i$ vojne elite na odluku o pristupanju Jugoslavije Trojnom paktu, demonstracije u Beogradu $i$ vojni puč. Rad sadrži prikaz stavova i informacija sovjetske diplomatije o uzrocima vojnog puča, karakteru demonstracija, sastavu nove vlade, kao i procene o budućim političkim koracima novoformiranog kabineta Dušana Simovića.

KLJUČNE REČI: Jugoslavija, SSSR, Nemačka, diplomatija, 27. mart, vlada, vojni puč

Jugoslovenska kraljevina i Sovjetska Rusija od proleća 1919. nisu imale diplomatske odnose. Uprkos različitim pokušajima da se uspostave zvanični diplomatski kontakti između Kraljevine SHS i Sovjetskog Saveza do toga nije došlo sve do leta 1940. Strah od širenja boljševizma, prijem velikog broja ruskih izbeglica nakon poraza „belih“ u građanskom ratu, politika velikih sila i njihovi interesi na Balkanu, kao i lični animoziteti kralja Aleksandra I, a potom i kneza Pavla, učinili su da dve zemlje tek u predvečerje Drugog svetskog rata započnu pregovore o normalizaciji međusobnih odnosa. Pregovori koji su počeli u leto 1939, a koji su usled sovjetske intervencije u Poljskoj i započinjanja rata s Finskom bili privremeno zakočeni, rezultirali su u proleće 1940. potpisivanjem trgovinskog ugovora, a potom i punom normalizacijom odnosa. U uslovima narastanja vojne opasnosti i ekspanzije Italije i Nemačke na Balkanu, kao i pod utiskom vojnog sloma Francuske, jugoslovenska vlada i generalštab su nastojali da obezbede strategijski oslonac na Sovjetski Savez i dobiju neophodnu vojnu pomoć iz te zemlje. Iako su sovjetski predstavnici obećavali traženu pomoć i sa jugoslovenskom stranom vodili intenzivne razgovore o tome, usled niza teškoća političkog i vojnog karaktera, kao i zahlađenja odnosa na prelazu iz 1940. u 1941. pomoć nije isporučena. Na drugoj strani, Sovjetski Savez je nastojao da parira nemačkom prodoru na Balkan težeći da spreči pristupanje balkanskih 
zemalja Trojnom paktu. Nakon bugarskog prilaska Osovini pomoć Jugoslaviji je postala gotovo nemoguća, a sovjetska diplomatska projekcija da se Balkan iskoristi kao ključna tačka oko koje će se sa Nemačkom pregovarati i na taj način dobiti neophodno vreme za odlaganje očekivanog nemačkog napada na Sovjetski Savez - neostvariva. Svesni svoje političke nemoći na samom terenu, Sovjeti su 23. marta 1941. uložili poslednji adut nudeći Jugoslaviji potpisivanje sporazuma o prijateljstvu i nenapadanju u slučaju da jugoslovenska vlada odbije ponuđeni pakt s Nemačkom. ${ }^{1}$

Događaji od 27. marta 1941. ostavili su na snazi jugoslovensko pristupanje Trojnom paktu, ali su suštinski iz korena izmenili jugoslovensku spoljnopolitičku poziciju. ${ }^{2}$ U odnosu na same događaje od 26/27. marta nema dokaza da je sovjetska strana učestvovala u pripremi i izvođenju vojnog udara. Ako se izuzme tvrđenje tadašnjeg zamenika načelnika Prve (Obaveštajne) uprave Narodnog komesarijata za unutrašnje poslove (NKVD) SSSR-a generala Pavela Sudoplatova, koje na osnovu raspoloživih izvora nije moguće potvrditi, da je Sovjetski Savez bio umešan u pripreme prevrata i da je u tu svrhu u Beograd upućen zamenik načelnika vojne obaveštajne službe, drugih dokaza nema. ${ }^{3}$ Uprkos tome što su beogradski demonstranti na ulicama vatreno klicali Sovjetskom Savezu i zahtevali „savez sa Sovjetskom Rusijom“, reakcije sovjetskih diplomatskih službenika u jugoslovenskoj prestonici su bile veoma suzdržane. Demonstranti koji su se u povorci kretali od Tehničkog fakulteta ulicama Kraljice Marije i Kralja Aleksandra su se u jednom momentu zaustavili pred zgradom sovjetskog poslanstva u Ulici Jovana Ristića. Iako su očekivali da će im se neko obratiti i pozdraviti ih, niko nije izašao iz zgrade kako bi pozdravio demonstrante. ${ }^{4}$ Sasvim sigurno, sovjetski predstavnici u Beogradu u nedostatku drugačijih instrukcija nisu odstupali od utvrđene linije sovjetske politike koja je podrazumevala strogo držanje neutralnog političkog i vojnog kursa uz neprovociranje nemačkih reakcija. Pošto je štampa na Zapadu, kao i u neutralnim zemljama prenela vest da je sovjetska vlada zvanično čestitala Simovićevoj vladi,

\footnotetext{
${ }^{1}$ O jugoslovensko-sovjetskim odnosima opširnije: Slavoljub Cvetković, ,Jugoslovensko-sovjetski pregovori 1941. o zaključenju ugovora o prijateljstvu i nenapadanju“, Vojnoistorijski glasnik, br. 1, (1991), 11-26; Миле Бјелајац, „Покушај стратешког ослонца на СССР 1939-1941“, Bojноисторијски гласник, бр. 1-2, (2006), 41-66; Александар Животић, Југословенскосовјетски односи 1939-1941 (Београд: Филип Вишњић, 2016); Владимир К. Волков и Леонид Я. Гибианский, Восточная Европа между Гитлером и Сталиным 1939-1941 (Москва: Индрик, 1999); Леонид Я. Гибианский, „Советский Союз и сербский военный переворот 27 марта 1941 года: историческая действительность, мифы, загадки“, у: Из истории Сербии и русско-сербских связей. 1812-1912-2012, уредник Константин В. Никифоров (Москва: ИнСлав РАН, 2014), 210-264.

${ }^{2}$ O 27. martu 1941. opširnije: Живан Кнежевић, 27. март 1941 (New York : Ж. Л. Кнежевић, 1979); Branko Petranović i Nikola Žutić, 27. mart 1941. Tematska zbirka dokumenata (Beograd: Nicom, 1990); Момчило Павловић, уредник, 27. март 1941. Седамдесет година касније. Зборник радова (Београд: Институт за савремену историју, 2012).

3 Павел Судоплатов, Разведка и Кремль: Записка нежелательного свидетеля (Москва: Олма пресс, 1996), 136-137.

${ }^{4}$ Branko Petranović, Srbija u Drugom svetskom ratu 1939-1941 (Beograd: Vojnoizdavački i novinski centar, 1992), 82.
} 
moskovska Pravda je to demantovala uz opasku da jugoslovenskoj vladi ipak treba čestitati što je ubrzo prenela zapadna štampa. ${ }^{5}$ Zato se nameće pitanje kako je i na koji način sovjetska diplomatija sagledavala dešavanja u Beogradu 26/27. marta 1941? Delimičan odgovor na to pitanje pružaju novopronađeni dokumenti fonda Sekretarijata narodnog komesara za inostrane poslove SSSR-a Vjačeslava Mihailoviča Molotova koji se čuvaju u okviru Arhiva spoljne politike Ruske Federacije.

Prve pouzdanije informacije o tome šta se zapravo desilo u Beogradu $u$ noći 26/27. marta 1941. sovjetski Narodni komesarijat za inostrane poslove (NKID) dobio je tokom 27. marta od svog ambasadora u Ankari Sergeja Vinogradova koji je odmah po prijemu vesti o prevratu u Beogradu posetio jugoslovenskog kolegu Iliju Šumenkovića, ${ }^{6}$ u nameri da se informiše o minulim dešavanjima. ${ }^{7}$ Inače, Vinogradov i Šumenković su održavali bliske kontakte, često razmenjivali informacije i konsultovali se o mnogim pitanjima od obostrane važnosti. Šumenković je na sovjetskoj strani uživao poseban ugled zbog svoje uloge u pregovorima o uspostavljanju diplomatskih odnosa između Jugoslavije i Sovjetskog Saveza, smatran je pobornikom bliske saradnje dve zemlje, ali i anglofilom i izuzetno dobro obaveštenim čovekom što ga je kvalifikovalo kao pouzdanog, dobronamernog i često nezaobilaznog sagovornika. ${ }^{8}$ Iako je Šumenković bio uzdržan u komentarima, Vinogradov je uspeo da od njega sazna važne informacije o tome šta se desilo u Beogradu i kakav je sastav novoobrazovanog kabineta. Ilija Šumenković je govorio o tome da su u novu vladu ušli predstavnici svih političkih partija, uključujući i onih koje su se poslednjih godina nalazile u opoziciji. Ta činjenica je slikovito govorila o čvrstini nove vlade i o tome da je u njoj ,sada predstavljen ceo narod“, ocenio je Šumenković. Isticao je kao važnu činjenicu da se u njoj nalazi Vlatko Maček koji ,predstavlja 90\% Hrvata“, dok je za profesora Slobodana Jovanovića govorio da je jedan od

\footnotetext{
${ }^{5}$ А. Животић, Југословенско-совјетски односи 1939-1941, 361.

${ }^{6}$ Ilija Šumenković (Niš, 1884 -Meksiko, 1962). Diplomirao je na Pravnom fakultetu u Beogradu i doktorirao u Parizu. U mladosti je pripadao Samostalnoj radikalnoj stranci. Učestvovao je u Četničkoj akciji. Po drugi put je dobrovoljno stupio u četnički odred kojim je komandovao Božin Simić (1912). U diplomatsku službu je stupio iste godine. Potom je bio pisar i sekretar poslanstva u Sofiji. Odatle je premešten u zvanju sekretara u Pariz, pa u London. Tokom Prvog svetskog rata je zajedno s Milanom Gavrilovićem bio sekretar Nikole Pašića. Od osnivanja 1919. bio je član Demokratske stranke. Godine 1920. dao je ostavku na rad u diplomatskoj službi. Bio je narodni poslanik u više skupštinskih saziva (1920-1929). Pre uvođenja ličnog režima kralja Aleksandra I napustio je Demokratsku stranku. Više puta je bio član vlade i obavljao dužnosti ministra trgovine i industrije (1924, 1932-1934), građevina (1927-1928), bez portfelja i zastupnika ministra inostranih poslova (1928-1929), pravde (1932) i prosvete (1934). Vratio se u diplomatsku službu 1929. Potom je bio stalni delegat pri Društvu naroda. Postavljen je za ambasadora u Ankari 1939. Na toj dužnosti je ostao do avgusta 1945.

7 Архив внешней политики Российской Федерации (AVPRF), фонд 6 - Секретариат Молотова (6), опись 3 (о.3), дело 298 (d.298), папка 22 (р.22), лист 259 (1.259).

${ }^{8} \mathrm{O}$ ulozi Ilije Šumenkovića u uspostavljanju jugoslovensko-sovjetskih odnosa opširnije: Миладин Милошевић, „Успостављање дипломатских односа између Краљевине Југославије и СССР-а 1940. године“, Историјски записи, 3-4, (2002), 99-124; А. Животић, Југословенско-совјетски односи 1939-1941, 157-188.
} 
„ljudi s najvećim autoritetom u Jugoslaviji“ koji je otvoreno istupao protiv pristupanja Jugoslavije Trojnom paktu. ${ }^{9}$ Momčilo Ninčić, novi ministar inostranih poslova, već se nekoliko puta nalazio na tom mestu i u tom svojstvu je 1922. dao zvaničnu izjavu da Jugoslavija ,neće ući ni u kakvu kombinaciju uperenu protiv Sovjetske Rusije“،, istakao je Šmenković. ${ }^{10}$ Za njega je posebno ohrabrujuća činjenica bila i to što je u novu vladu u svojstvu ministra bez portfelja ušao Milan Gavrilović, lider Saveza zemljoradnika, aktuelni jugoslovenski poslanik u Moskvi i blizak Šumenkovićev prijatelj koji je na njegovu preporuku i postavljen na to mesto. U pogledu budućih koraka novoformirane vlade Šumenković je bio dosta rezervisan smatrajući da je teško o tome govoriti jer se u njoj nalaze i pristalice i protivnici jugoslovenskog pristupanja Trojnom paktu. ${ }^{11}$ Naizgled, informacije i lični utisci koje je Šumenković preneo Vinogradovu deluju banalno $\mathrm{i}$ bez velike vrednosti, ali se veoma brzo pokazalo da su u nedostatku kvalitetnih informacija iz Beograda upravo one dobrim delom poslužile sovjetskoj diplomatiji pri formiranju slike o karakteru vojnog puča, sastavu nove jugoslovenske vlade i predikciji njenih političkih poteza koji su se u Moskvi s nestrpljenjem i zebnjom iščekivali.

Pošto su veze između Moskve i sovjetskog poslanstva u Beogradu bile otežane, a i samo poslanstvo se nakon zahlađenja odnosa krajem 1940. usled špijunske afere s dopisnikom TASS-a Roždestvenskim nalazilo pod policijskom prismotrom, sovjetske diplomate su teško dolazile do pouzdanih informacija, pa su iz Beograda u Moskvu vesti stizale sa zakašnjenjem. Sem toga, sužen obim kontakata sa zvaničnim predstavnicima jugoslovenske vlade koje je sovjetski poslanik imao u Beogradu, postao je još uži nakon njegovog povlačenja januara 1941, pa je sovjetsko predstavništvo u Beogradu raspolagalo ograničenim kvantumom pouzdanih informacija. ${ }^{12}$ Zato su informacije koje je ambasador Vinogradov dobio u razgovoru sa Šumenkovićem dobrim delom poslužile načelniku Bliskoistočnog odeljenja NKID-a Nikolaju Novikovu ${ }^{13}$ da uz informacije o političkim kretanjima u Jugoslaviji kojima je ranije raspolagao sačini prvu zvaničnu informaciju o događajima u Beogradu namenjenu sovjetskom državnom vrhu. ${ }^{14}$ On je već u popodnevnim časovima 27 . marta

\footnotetext{
${ }^{9}$ AVPRF, 6, o.3, d. 298, p. 22, 1. 259.

${ }^{10}$ O Ninčićevom odnosu prema Sovjetskom Savezu opširnije: Александар Животић, „Покушај успостављања дипломатских односа између Југославије и Совјетског Савеза (19231927)“, у: Русија/ СССР и државност Србије/Југославије, уредници Срђан Рудић и Константин В. Никифоров (Београд: Историјски институт, 2018), 299-322.

${ }^{11}$ AVPRF, 6, o.3, d. 298, p. 22, 1. 260.

12 А. Животић, Југословенско-совјетски односи 1939-1941, 308-313.

${ }^{13}$ Nikolaj Vasiljevič Novikov (1903-1989). Po završetku Lenjingradskog istočnog instituta radio je u Ministarstvu spoljne trgovine SSSR-a i povremeno predavao ekonomiju Turske i bliskoistočnog sveta na Moskovskom institutu za istočne studije. Od 1938. radio je u Narodnom komesarijatu za inostrane poslove SSSR-a kao konsultant Prvog istočnog odeljenja, a potom načelnik Bliskoistočnog i Četvrtog evropskog odeljenja. Od 1943. bio je ambasador u Egiptu i istovremeno pri vladama u izbeglištvu Grčke i Jugoslavije. Ambasador u Vašingtonu (19461947). Član Saveza pisaca SSSR-a od 1950.

${ }^{14}$ AVPRF, 6, o.3, d. 373, p. 27, 1. 3.
} 
1941. uputio informaciju Vjačeslavu Molotovu da događaji koji su se zbili u Jugoslaviji - tu je mislio na ,hapšenje premijera Dragiše Cvetkovića i dovođenje na presto kralja Petra Karađorđevića, koji je trebalo da dođe na presto 6. septembra 1941“ - predstavljaju rezultat nezadovoljstva koje se u ,poslednje vreme nakupilo unutar širokih slojeva Jugoslavije zbog kapitulantske politike u odnosu na Nemačku koju je sprovodila vlada koja je svrgnuta“. Kasnije je u svojim sećanjima Novikov ocenio da se radilo o ,patriotskim krugovima koji su na sebe preuzeli inicijativu borbe protiv kapitulanata“. ${ }^{15} \mathrm{U}$ vezi sa komešanjem unutar Cvetkovićevog kabineta, znalo se da su ministri Branko Čubrilović i Srđan Budisavljević podneli ostavke u znak protesta prema politici koju su po Novikovljevim zaključcima oličavali knez Pavle, Dragiša Cvetković i ministar inostranih poslova Aleksandar Cincar-Marković. Takva politika je bila nepopularna „među širokim masama jugoslovenskog naroda“ koji je „na svojim leđima iskusio politiku ustupaka Nemačkoj u oblasti ekonomije“, ocenjuje Novikov. O samim demonstracijama koje su započele 26. marta raspolagalo se samo informacijama dobijenim od dopisnika TASS-a iz Beograda koje su govorile da je u mnogim jugoslovenskim gradovima održan ,niz mitinga i demonstracija i da je na njima učestvovalo nekoliko desetina hiljada ljudi““. Među parolama sa demonstracija sovjetska diplomatija je apostrofirala „Dole Hitler“, „Dole peta kolona“ i ,Savez s Rusijom“. ${ }^{16}$

Ono što je za sovjetsku diplomatiju bilo zbunjujuće, jeste sastav nove vlade. Novikov nije uspevao da objasni kako se desilo da u novoj vladi nastaloj na krilima svrgavanja stare vlade koja je pristupila Trojnom paktu bude zadržano čak 8 ministara, od kojih su se šestorica saglasila s prilaskom Jugoslavije Osovini, a dvojica u znak protesta podnela ostavke. O predsedniku vlade generalu Dušanu Simoviću se raspolagalo vrlo šturim podacima koji su govorili da je bio načelnik generalštaba do januara 1940. kad je smenjen i da je od jeseni 1940. bio na čelu jugoslovenskog vazduhoplovstva. Za Slobodana Jovanovića se isticalo da se radi o poznatom profesoru Beogradskog univerziteta koji se smatra „poznavaocem srpske istorije“. Posebno se naglašavalo da je on povodom 23-godišnjice Oktobarske revolucije poslao čestitku sovjetskom poslanstvu u Beogradu. Posebna pažnja je posvećena analizi ličnosti ministra inostranih poslova Momčila Ninčića, koji je bio ministar u mnogim ranijim vladama. Ocenjivalo se da on - kao član Narodne radikalne stranke koja se nalazila u opoziciji u odnosu na Cvetkovićevu vladu i bivši ministar inostranih poslova koji je u tom svojstvu podržavao inicijative za uspostavljanje odnosa Jugoslavije i Sovjetskog Saveza - može da utiče na nov spoljnopolitički kurs vlade usmeren ka približavanju SSSR-u. ${ }^{17}$ I za Ninčića, kao i za ministre Srđana Budisavljevića, Ivana Andresa, Branka Čubrilovića, Džafera Kulenovića i Josipa Torbara, uz potpredsednika vlade Vlatka Mačeka, smatralo se da su po svom političkom opredeljenju anglofili. Novikov je, iz tih razloga, zaključio da je nova vlada ,po

\footnotetext{
${ }^{15}$ Николай В. Новиков, Воспоминания дипломата (Москва: ИПЛ, 1989), 82.

${ }^{16}$ AVPRF, 6, o.3, d. 373, p. 27, 1. 3.

${ }^{17}$ AVPRF, 6, o.3, d. 373, p. 27, 1. 4.
} 
svom sastavu antinemački opredeljena“. Sami uzroci puča su, u nedostatku detaljnijih informacija kojim bi se objasnila politička klima u Jugoslaviji i implikacije međunarodnih odnosa na političke odnose u jugoslovenskoj kraljevini, nalaženi u ideologizovanim i šablonskim formama tumačenja. Tako se ocenjivalo da su „vladajući jugoslovenski krugovi“ odlučili da izvedu prevrat pod pritiskom „nezadovoljnog dela buržoazije“ koji se protivio „Cvetkovićevoj politici kapitulacije pred Nemačkom“ i straha da bi ,radničke mase koje su istupale protiv takve politike mogle same da sruše Cvetkovićevu vladu“. Sovjetska diplomatija je čvrsto stajala na stanovištu da su minuli događaji bili ,,snažno potpomognuti od strane engleske agenture" i da će Velika Britanija učiniti sve da iskoristi prevrat u svrhu ispunjenja svojih interesa na Balkanu. ${ }^{18}$ Elaborat koji je Nikolaj Novikov sačinio za donosioce najvažnijih odluka u vrhu sovjetske spoljne politike jasno svedoči o nedostatku pravovernih informacija o političkim odnosima u Jugoslaviji, uzrocima nezadovoljstva znatnog dela intelektualne, političke i vojne elite politikom vlade Cvetković - Maček, kao i o raspoloženju u samom narodu. Nedostatak informacija, kao i ideološka klima koja je vladala u vrhu sovjetske diplomatije nakon ,,velike čistke“ 1936-1938, objašnjavaju krajnje ideologizovana tumačenja unutrašnjih odnosa u Jugoslaviji i realne političke snage radničke klase.

Sovjetsko poslanstvo u Beogradu poslalo je informacije o dešavanjima u noći 26/27. marta 1941. u Moskvu 28. marta. Otpravnik poslova u Beogradu Viktor Lebedev ${ }^{19}$ je u informaciji NKID-u pisao da su demonstracije protiv pristupanja Jugoslavije Trojnom paktu započele u Beogradu još 26. marta popodne i da su se brzo proširile po drugim gradovima. U Kragujevcu je na demonstracijama prema njegovim izvorima informisanja učestvovalo oko 10.000 ljudi, dok su u drugim gradovima demonstranti takođe bili brojni. Policija je pokušavala da razbije demonstracije, ali nije upotrebila oružje. Nakon što su u noći 26/27. marta generali Dušan Simović, Borivoje Mirković i Bogoljub Ilić izvršili državni udar, objavljeno je da je maloletni kralj Petar II stupio na presto. Beograd je 27. marta osvanuo ukrašen nacionalnim zastavama, a ,ceo grad je izašao na ulice“, javljao je Lebedev. Stekao je utisak da je zemlja ,s likovanjem“ dočekala državni udar i da je u narodu taj akt doživljen kao ,negacija ponižavajućeg pakta s Osovinom“. Prilikom demonstracija demolirani su nemački turistički biro i nekoliko prodavnica nemačke robe. Posebno je bio oduševljen demonstrantima koji su se okupljali oko zgrade sovjetskog poslanstva i isticali parole u čast Sovjetskog Saveza. Uverio se da su se slične parole mogle čuti i videti među

\footnotetext{
${ }^{18}$ AVPRF, 6, o.3, d. 373, p. 27, 1. 5.

19 Viktor Zaharevič Lebedev (1900-1968). Završio je Rjazanski pedagoški institut 1922. i Moskovski državni univerzitet 1925. U diplomatskoj karijeri bio je savetnik sovjetskog poslanstva u Beogradu (1940-1941), zamenik načelnika Međunarodnog odeljenja Sovinformbiroa (1941-1943), ambasador pri vladama u egzilu Jugoslavije, Holandije, Belgije, Luksemburga i Norveške u Londonu (1943-1945), ambasador u Poljskoj (1945-1951), poslanik u Finskoj (1951-1954), ambasador u Finskoj (1954-1958), ekspert za pitanja objavljivanja diplomatskih dokumenata (1958-1960), rektor Visoke diplomatske škole Ministarstva inostranih poslova SSSR (1960-1965).
} 
demonstrantima i u drugim delovima Beograda. Svedočio je da su se parole prijateljstva pred sovjetskim poslanstvom svega nekoliko desetina metara dalje pred poslanstvom Nemačke pretvarale u parole neprijateljstva. To je nateralo beogradske policijske vlasti da postave jake straže u toj ulici, tako da uveče 27. marta demonstranti nisu mogli da se približe zgradi sovjetske diplomatske misije, ali su se u daljini i dalje mogle čuti parole kojima se tražio savez sa Rusijom. ${ }^{20}$ Lebedev je nastojao da što vernije prenese atmosferu s beogradskih ulica, ali još uvek nije raspolagao informacijama šta se zapravo desilo tokom prethodne noći, dok je u pogledu budućih spoljnopolitičkih koraka jugoslovenske vlade mogao samo da pretpostavi u kojem će pravcu oni ići.

Nasuprot sovjetskoj diplomatiji koja je raspolagala znatno suženim, ali prilično tačnim informacijama, vojna diplomatija SSSR-a je u prvim momentima imala dosta neprecizne informacije. Prema vestima koje su u Moskvu stizale od sovjetskih vojnih izaslanika u Sofiji i Berlinu, do prevrata je došlo nakon što je knez Pavle tokom susreta u Sloveniji s ministrom inostranih poslova Trećeg rajha Joakimom Ribentropom dobio od Hitlera saglasnost „na jugoslovensku krunu“ i navodno je u noći 26/27. marta pokušao da protera kralja Petra II u Rumuniju, ali su to osujetili „ljudi generala Simovića“ koji su navodno presreli voz i mladog kralja vratili u Beograd. Zato je navodno knez Pavle, saznavši za opasnost, krenuo da beži iz Beograda, ali je uhapšen na šestoj stanici od Beograda u pravcu Zagreba. Istog jutra su, prema tim informacijama, uhapšeni premijer Dragiša Cvetković i ostali ministri. ${ }^{21}$ Nasuprot informacijama kojima su raspolagali sovjetski vojni izaslanici, ne postoje ili nam nisu poznati istorijski izvori koji bi potvrdili da je uopšte došlo do susreta kneza Pavla i Ribentropa u Sloveniji, a još manje da je tom prilikom knezu Pavlu od strane Nemaca ponuđena jugoslovenska kruna. ${ }^{22}$ Prema istim izvorima, jedinice garde i beogradskog garnizona su zauzele važne punktove u gradu, a maloletni kralj Petar II je preuzeo vlast i poverio mandat za sastav nove vlade generalu Simoviću. Vesti su govorile i da se održavaju demonstracije po čitavoj zemlji, a da pored zgrade sovjetskog poslanstva u Beogradu prolaze demonstranti koji uzvikuju parole protiv Nemačke i zahtevaju savez sa SSSR-om. U pogledu držanja vojske, ocenjivano je da je ona u potpunosti na strani nove vlade $\mathrm{i}$ da održava red u zemlji. Pretpostavljalo se da će nova vlada insistirati na strogo neutralnoj spoljnopolitičkoj poziciji i da će se odreći pristupanja Trojnom paktu.

Sovjete je zabrinjavala moguća nemačka reakcija na dešavanja u Beogradu, pogotovo što s nemačke strane nije bilo nikakvih zvaničnih saopštenja.

20 „Из письма поверенного в делах СССР в Югославии В. З. Лебедева в НКИД СССР о государственном перевероте в Югославии и проявлениях симпатиях со стороны жителей Белграда 28 марта 1941“, у: Советско-югославские отношения 1917-1941, уредник Владимир Зеленин (Москва: Наука, 1992), 363.

21 „Спецсообщение Разведуправления Генштаба Красной армии К перевороту в Югославии“, у: Военная разведка информирует. Документы Разведуправления Красной армии: январь 1939-июнь 1941, уредник Виктор А. Гаврилов (Москва: Демократия, 2009), 575.

22 Jacob B. Hoptner, Jugoslavija u krizi 1934-1941 (Rijeka: Otokar Keršovani, 1973), 209-223. 
Sovjetska vojna diplomatija je pretpostavljala da će u slučaju da nova jugoslovenska vlada odstupi od prilaska Trojnom paktu uslediti vojna akcija protiv Jugoslavije s prostora Austrije, Rumunije i Bugarske. Na osnovu presretnutog telegrama američkog dopisnika iz Beograda, Sovjeti su saznali da je pomoćnik nemačkog vojnog atašea zadužen za vazduhoplovne poslove ranjen, da su demonstranti demolirali sva vozila na kojima se nalazila „svastika“ i da je nemačkoj koloniji naloženo da započne evakuaciju iz Beograda. Sovjetski vojni ataše u Sofiji je dobio netačnu informaciju da je prethodna jugoslovenska vlada tajnim protokolom u Beču preuzela obavezu da pusti nemačke vojne snage na ograničen prostor na samom jugu zemlje. U pogledu vojnih priprema za slučaj nemačkog napada, sovjetska vojna diplomatija je raspolagala informacijama da je nova vlada preduzela potrebne mere za organizaciju odbrane zemlje, a da su neke preduzete još pre pristupanja Jugoslavije Trojnom paktu. Do njih su dolazile i vesti o ograničenoj vojnoj mobilizaciji i koncentraciji jedinica 2, 3. i 5 . jugoslovenske armije na istočnim i jugoistočnim granicama, a pretpostavljalo se da će uskoro započeti mobilizacija i koncentracija jedinica 1. i 4. jugoslovenske armije na severnim i zapadnim državnim granicama, odnosno da će ukupna jugoslovenska vojna snaga sa 26 divizija i 6 samostalnih brigada uskoro dostići snagu između 48-50 divizija i 10 samostalnih brigada sa ukupno od 1,2 do 1,3 miliona ljudi pod oružjem. ${ }^{23}$ Informacije kojima je raspolagala sovjetska vojna diplomatija, pa samim tim i vojna obaveštajna služba, nisu bile tačne u delu koji se ticao samog prevrata u Beogradu, njegovih uzroka i načina na koji je izveden. Takođe, u pogledu procene jugoslovenskih vojnih snaga radilo se o tačnim informacijama o stanju ukupnih jugoslovenskih mobilizacijskih kapaciteta, ali se jasno vidi da su Sovjeti ipak slabo poznavali specifičnosti jugoslovenske vojne organizacije i da su broj jugoslovenskih divizija određivali na osnovu pretpostavke da je njena formacija slična nemačkoj, britanskoj ili sovjetskoj. Tako je procenjeno da Jugoslavija raspolaže dvostruko većim brojem divizija nego što je to bilo u stvarnosti, a u samoj stvarnosti brojnost jedne njene divizije je bila dvostruko veća od onih u drugim modernim armijama.

Nekoliko dana po 27-martovskom prevratu, u momentima kad su već započeli intenzivni pregovori o sklapanju sporazuma o prijateljstvu između Jugoslavije i Sovjetskog Saveza, na osnovu prikupljenih informacija i u svetlu događaja koji su usledili neposredno po državnom udaru, načelnik Bliskoistočnog odeljenja NKID-a Novikov je izradio temeljniju analizu događaja od 26/27. marta i dostavio je sovjetskom državnom vrhu 5. aprila 1941. Analizirajući jugoslovensku spoljnopolitičku poziciju, Novikov je smatrao da je Jugoslavija od samog nastanka imala važno mesto u anglo-francuskim planovima na Balkanu i da je predstavljala jednu od njihovih oslonih tačaka na Balkanu, a da je u poslednjim mesecima u svetlu ulaska Italije u rat, pada Francuske i prodora Nemačke na Balkan upala u svojevrsnu spoljnopolitičku izolaciju. Ocenjivano

23 „Спецсообщение Разведуправления Генштаба Красной армии К перевороту в Югославии“, у: Военная разведка информирует. Документы Разведуправления Красной армии: январь 1939-июнь 1941, 575-576. 
je da je pod nemačkim pritiskom Jugoslavija bila primorana da potpiše čitav niz za sebe nepovoljnih ekonomskih sporazuma, posebno u oblasti izvoza značajnih količina poljoprivrednih proizvoda koji su bili deficitarni i u samoj zemlji. Tvrdilo se da je nemački pritisak na Jugoslaviju sprovođen i putem mnogobrojne nemačke agenture i pronemački raspoloženih novinara i političara. Kao nosioci nemačkog uticaja imenovani su bivši ministar inostranih poslova Aleksandar Cincar-Marković, direktor „Vremena“ Danilo Gregorić i šef beogradske policije Drinčić. ${ }^{24} \mathrm{U}$ takvim uslovima Cvetkovićeva vlada je, po sovjetskim ocenama, sprovodila politiku laviranja i neprekidnih ustupaka. Rezultatom takve politike je smatrano davanje Nemačkoj prava da Dunavom prevozi ratni materijal u Rumuniju i kao finale zahtev Jugoslaviji da pristupi Trojnom paktu. U takvim uslovima, prema sovjetskim ocenama, jugoslovenska vlada nije mogla više da lavira i morala je da donese konačnu odluku - da pristupi paktu ili se suoči s vojnom agresijom. Za Sovjete je jugoslovensko pristupanje Trojnom paktu bilo znak da Cvetkovićeva vlada nije u stanju da pruži otpor nemačkim zahtevima i da je primorana da krene putem Rumunije i Bugarske. ${ }^{25}$ Smatrali su da ni Nemci ni vlada nisu realno procenjivali odnos političkih snaga u zemlji i raspoloženje u samom narodu, te da zato nisu bili u stanju da predvide buduće događaje $i$ karakter reakcija javnosti na takav korak vlade. Ostavke ministara Budisavljevića i Čubrilovića su smatrali vesnikom budućeg nezadovoljstva. Za Sovjete je od posebne važnosti bilo to što demonstracije nisu imale samo antivladin i antinemački karakter, već i izrazito prosovjetsko obeležje. ${ }^{26}$

O samoj ulozi vojnog faktora u izvođenju državnog udara se veoma malo znalo. Informacije sovjetske diplomatije o ulozi vojske u prevratu oslanjale su se dobrim delom na vesti koje su se mogle naći u zapadnoj štampi i čuti na različitim radio stanicama. Zaključivalo se da je uloga vojske bila ogromna i da je vojni faktor bio podržan od strane predstavnika opozicionih političkih partija. U pogledu uloge mladog kralja, zaključeno je da on nije imao nikakvu realnu ulogu u prevratu i da je od strane vojske suočen sa svršenim činom. Vezano za sam sastav nove vlade, Sovjeti su stajali na stanovištu da se radi o veoma šarolikom kabinetu u kome je predstavljena većina političkih i nacionalnih grupacija i da upravo ta okolnost predstavlja otežavajuću tačku pri donošenju zaključka o budućoj spoljnopolitičkoj orijentaciji vlade. Ipak, na osnovu podataka o ranijim političkim simpatijama nekolicine članova vlade, zaključivano je da će ipak vlada zauzeti ,,antinemačku poziciju““ ${ }^{27}$ Za Sovjete je od posebne važnosti bilo pitanje budućeg držanja hrvatskih ministara u novoj vladi jer su procenjivali da od toga neće zavisiti samo stabilnost kabineta, već i same države. Za hrvatske ministre su znali da su podržali pristupanje Trojnom paktu i pretpostavljali da su za ulazak u nov kabinet postavili uslove vezane za ostanak na snazi pristupa Trojnom paktu u cilju izbegavanja sukoba s Nemačkom. Sovjete je zabrinjavalo

\footnotetext{
${ }^{24}$ AVPRF, 6, o.3, d. 373, p. 27, 1. 6.

${ }^{25}$ AVPRF, 6, o.3, d. 373, p. 27, 1.7.

${ }^{26}$ Isto.

${ }^{27}$ AVPRF, 6, o.3, d. 373, p. 27, 1.8.
} 
to što je Vlatko Maček, lider Hrvatske seljačke stranke, dao pristanak za svoj ulazak u vladu tek nakon nekoliko dana pregovora. Pretpostavljalo se da je postavio kao uslov priznanje hrvatske autonomije i izbegavanje rata s Nemačkom, kao i stvaranje Krunskog saveta koji bi činili po jedan predstavnik srpskog, hrvatskog i slovenačkog naroda. Sovjetska diplomatija je smatrala da će Nemačka pokušati da iskoristi uticajnu grupu hrvatskih ministara radi raspirivanja srpsko-hrvatskog sukoba. Za istu grupu ministara se procenjivalo da će stremiti postizanju kompromisa s Nemcima i pretpostavljalo da je upravo ona uticala na ministra Ninčića da nemačkom poslaniku Herenu da izjavu 30. marta o tome da Jugoslavija ostaje i dalje pri pristupanju Trojnom paktu. ${ }^{28}$ Ipak, procenjivano je da će nova jugoslovenska vlada u odnosu na Nemačku ići samo na formalne ustupke, a da će suštinski voditi ,antinemačku politiku“ i težiti dobijanju vremena za izvođenje neophodnih mobilizacijskih priprema i različitih spoljnopolitičkih akcija. Kao dokaz takve tvrdnje korišćena je okolnost da je jugoslovenska vlada odbila nemački zahtev da izvrši demobilizaciju jugoslovenske vojske i da je nakon prevrata započela $\mathrm{s}$,,čistkom unutar vojnih redova $\mathrm{i}$ državnog aparata“, odnosno da je pored hapšenja i internacije dela ministara iz stare vlade smenjen i znatan broj oficira generalštaba koji nisu krili svoje simpatije prema Nemačkoj. U tom cilju su prema sovjetskim informacijama na mnoga važna mesta u vojsci postavljene pristalice nove vlade, te su započete obimne odbrambene pripreme koje se graniče s opštom mobilizacijom. ${ }^{29}$

U pogledu budućih akcija Velike Britanije na Balkanu, Sovjeti su procenjivali da će Britanci pokušati maksimalno da iskoriste novonastalu situaciju u cilju stvaranja novog fronta koji bi činile Jugoslavija i Grčka, a možda i Turska uz podršku britanske bliskoistočne armije. To su dovodili u vezu s dolaskom britanskog ministra inostranih poslova Entonija Idna i načelnika imperijalnog generalštaba generala Džona Dila u Atinu. Po njima, postojala su dva moguća pravca budućih britanskih akcija na Balkanu. Jedan, koja bi podrazumevao zaključenje anglo-jugoslovenskog pakta o uzajamnoj pomoći i drugi koji bi podrazumevao akciju Jugoslavije, Grčke, Velike Britanije i Turske u cilju zajedničkog nastupanja ka severu i odbacivanja Nemaca preko Dunava. Sovjeti su otvoreno sumnjali u mogućnost turskog pristupanja takvom paktu. Smatrali su da će Turska ljubomorno čuvati svoju neutralnost sve do trenutka dok ne budu ugrožene njene evropske granice ili Nemci pak ne dođu do Soluna i egejskih ostrva koja se nalaze na putu ka Dardanelima, a da će se dotle isključivo ograničiti na pružanje „moralne podrške“. Nisu isključivali mogućnost turskog uključenja u sukob u slučaju rasplamsavanja ratnog požara usled efikasnijeg i dugotrajnijeg jugoslovenskog otpora Nemcima. U pogledu nemačkih reakcija, Sovjeti su primećivali da su Nemci u početku nastupali vrlo uzdržano, ali da su nakon toga gromoglasno započeli kampanju koja je insistirala na tome da jugoslovenska vlada drži sopstveni narod u potpunom neznanju u pogledu uzroka vojnog prevrata i ne informiše javnost o ozbiljnom položaju u koji je zemlja došla usled

\footnotetext{
${ }^{28}$ AVPRF, 6, o.3, d. 373, p. 27, 1. 9.

${ }^{29}$ AVPRF, 6, o.3, d. 373, p. 27, 1. 10.
} 
prevrata, da nemačka diplomatija neprestano govori o ,,antinemačkom delovanju jugoslovenske diplomatije“" $\mathrm{i}$ da Nemci insistiraju na tome da se jugoslovenska diplomatija nalazi pod snažnim uticajem stranih zemalja. Takođe, Sovjeti su primećivali da Nemci u svojim propagandnim nastupima insistiraju na teškom položaju svoje manjine u Jugoslaviji. To su za Sovjete bili znaci sve veće ugroženosti Jugoslavije od strane Nemačke.

Kao indikatore buduće agresije na Jugoslaviju Sovjeti su navodili ubrzanu koncentraciju nemačkih trupa na tlu Mađarske, Rumunije i Bugarske, evakuaciju nemačke kolonije iz Jugoslavije i odlazak nemačke diplomatske misije iz Beograda, izuzev otpravnika poslova i vojnog izaslanika. ${ }^{30}$ Sovjeti su stajali na stanovištu da napad na Jugoslaviju nije započeo samo zato što Nemci u tim momentima nisu raspolagali dovoljnim vojnim efektivima u regionu za početak akcije. Po sovjetskim izvorima, nemačke snage u Bugarskoj su bile prikupljene za akciju u Grčkoj, dok se za Jugoslaviju računalo da će zauzeti poziciju ,prijateljske neutralnosti““ ili čak i ukazati određenu pomoć Nemačkoj. ${ }^{31}$ Budući da nakon prevrata u Beogradu takva kombinacija nije bila moguća, sovjetska diplomatija je procenjivala da će Nemačka radi slabljenja Jugoslavije nastojati da podstakne srpsko-hrvatske sukobe i da će po ugledu na Slovačku obećati Hrvatima stvaranje nezavisne države, kao čvrstog mostobrana za dalje nemačko nastupanje unutar same Jugoslavije. Sovjeti su stajali na stanovištu da je Nemačka odustala od tih kombinacija i da će usled izmenjenih okolnosti ići na direktno rušenje Jugoslavije. Smatrali su da će u tom cilju Nemci nastojati da iskoriste i ,bugarske šovinističke organizacije“. 32 Pretpostavljali su da će Nemačka nastojati da u vojnu akciju protiv Jugoslavije uključi i Mađarsku. Sovjetsku stranu je ohrabrivalo italijansko držanje. Raspolagali su informacijama da će Musolini pokušati da deluje pomirljivo i utiče na Nemačku da odustane od vojnog napada na Jugoslaviju usled straha da bi položaj italijanske vojske u Albaniji postao nezavidan zbog zajedničke jugoslovensko-grčke vojne akcije na tom prostoru. ${ }^{33}$

$\mathrm{Na}$ sovjetskoj strani se procenjivalo da mere koje je jugoslovenska vlada preduzela na planu jačanja odbrambene moći zemlje ulivaju nadu da se ona ozbiljno sprema da pruži otpor Nemačkoj u slučaju vojnog napada i da $u$ tim okolnostima sovjetska podrška Jugoslaviji „u borbi za očuvanje nezavisnosti odgovara sovjetskim državnim interesima“. Sovjetska diplomatija je polazila od toga da ,sovjetska podrška Jugoslaviji ne bi sama po sebi bila apsolutna garancija da ona neće biti napadnuta od strane zemalja Osovine, ali da sama sovjetska podrška Jugoslaviji ima ogroman spoljnopolitički značaj za Jugoslaviju i da će ona ojačati sovjetske pozicije na Balkanu“. ${ }^{34}$ Svakako, takav pristup Jugoslaviji i njenom spoljnopolitičkom položaju presudno je uti-

\footnotetext{
${ }^{30}$ AVPRF, 6, o.3, d. 373, p. 27, 1. 11.

${ }^{31}$ AVPRF, 6, o.3, d. 373, p. 27, 1. 12.

${ }^{32}$ AVPRF, 6, o.3, d. 373, p. 27, 1. 13.

${ }^{33}$ AVPRF, 6, o.3, d. 373, p. 27, 1. 14.

${ }^{34}$ AVPRF, 6, o.3, d. 373, p. 27, 1. 15.
} 
cao na karakter sovjetsko-jugoslovenskog pakta o prijateljstvu i saradnji koji je potpisan u Moskvi u noći 5/6. aprila 1941. Na sovjetskoj strani su uočavani glavni unutrašnji politički problemi i izazovi s kojima se susretala jugoslovenska vlada, dok je na spoljnopolitičkom planu gotovo nepogrešivo skicirala pravce budućeg razvoja događaja.

Sovjetski otpravnik poslova u Beogradu Lebedev i vojni ataše general Aleksandar Samohin ${ }^{35}$ na nešto drugačiji način su videli događaje od 27. marta. Poput svojih kolega koji su službovali u Berlinu i Sofiji i oni su uzroke i povod vojnog puča objašnjavali navodnim pokušajem kneza Pavla da uz nemački pristanak i podršku sebe proglasi jugoslovenskim kraljem. ${ }^{36}$ Pišući svoju zajedničku analizu po povratku u Moskvu nakon jugoslovenskog vojnog poraza u Aprilskom ratu, isticali su da je rezultat vojnog udara od 27. marta trebalo da bude uspostavljanje bližih veza između Jugoslavije i Sovjetskog Saveza kao kontrateže nemačkom uticaju na Balkanu čemu je, prema njihovim ocenama, iskreno težila Simovićeva vlada. Smatrali su da je prethodna vlada bila pod snažnim germanofilskim uticajem i da je značajan uticaj na njenu politiku ispoljavala nemačka agentura, dok su nasuprot njima stajale stare građanske partije koje su nastupale sa probritanskih pozicija. U narodu je, po njihovoj oceni, postojalo jako rusofilsko raspoloženje što je u mnogome jačalo sovjetske pozicije u jugoslovenskom društvu, naročito njegovom srpskom delu. ${ }^{37}$ Svedočili su o izuzetnom antinemačkom i prosovjetskom raspoloženju demonstranata na beogradskim ulicama. ${ }^{38}$ Nasuprot NKID-u, koji je događaje tumačio dobrim delom gledajući kroz ideološku prizmu, oni su kao neposredni svedoci prednost davali vojnom u odnosu na politički faktor. Smatrali su da glavnu zaslugu imaju generali Simović, Ilić i Mirković i antinemački raspoloženi oficiri, kao i da je sam prevrat odrazio „raspoloženje širokih narodnih masa, u prvom redu srpskih“ odnosno srpskog naroda koji nije želeo da ,bude zavisan od Nemačke već da sačuva svoju nezavisnost".

\footnotetext{
${ }^{35}$ Aleksandar Georgijevič Samohin (1902-1955). U Crvenu armiju je stupio dobrovoljno 1918. Završio je vojnu školu u Kijevu 1923, a akademiju „Frunze“ 1934. Posle toga je bio načelnik operativnog odeljenja štaba divizije i načelnik štaba divizije. Potom je bio načelnik pešadijskog vojnog učilišta u Ordžonikidzeu i zamenik načelnika Glavne uprave vojnog školstva. Od septembra 1940. vojni izaslanik u Jugoslaviji. Na početku rata je komandovao jedinicama 29. korpusa na prostoru Litvanije koji je u prvim operacijama gotovo u potpunosti uništen. Potom je tokom Bitke za Moskvu bio zamenik komandanta za pozadinu slavne 16. armije kojom je komandovao budući proslavljeni maršal Konstantin Rokosovski. Krajem 1941, postavljen je na dužnost zamenika načelnika Druge uprave Glavne obaveštajne uprave Generalštaba Crvene armije, a februara naredne godine postao je načelnik iste uprave. Aprila 1942. postavljen je na mesto komandanta 48. armije Brjanskog fronta, ali nije preuzeo dužnost jer je avion kojim je prevožen na novu dužnost sleteo iza neprijateljskih linija, pa je Samohin zarobljen. Maja 1945. oslobođen je iz zarobljeništva, a krajem iste godine uhapšen. Osuđen je na 25 godina zatočenja, ali je oslobođen i rehabilitovan 1953. Radio je kao stariji predavač na vojnoj katedri Moskovskog državnog univerziteta.

${ }^{36}$ AVPRF, 6, o.3, d. 371, p. 27, 1. 24.

${ }^{37}$ AVPRF, 6, o.3, d. 371, p. 27, 1. 17-19.

${ }^{38}$ AVPRF, 6, o.3, d. 371, p. 27, 1. 25.
} 
Novu vladu su videli kao nekadašnji jugoslovenski parlament u malom sa svim njegovim unutrašnjim podelama i sukobima, što je na sovjetskoj strani izazivalo ozbiljne sumnje u njeno unutrašnje jedinstvo i sposobnost da se odupre nemačkim pritiscima. ${ }^{39}$ Po njima, upravo zato se nisu mogle izbeći ni tragikomične scene u noći prevrata kad budući ministri nisu znali kuda ih oficiri vode, da bi tek po dolasku u zgradu generalštaba saznali da su pozvani kako bi preuzeli određene resore u novoj vladi. ${ }^{40}$ Čvrsto su verovali da je Simovićeva vlada išla putem približavanja SSSR-u i da je brz početak rata nju omeo na tom putu. Za njegovu vladu su ocenjivali da je pokušala da izbegne rat s Nemačkom vodeći izbalansiranu politiku ravnoteže u odnosima Nemačke i Sovjetskog Saveza. ${ }^{41}$ Sam vojni prevrat su videli kao ogroman poraz nemačke obaveštajne službe na Balkanu, koja je bila prinuđena da svoje propuste ispravlja ,radikalnim sredstvima vojne agresije“. ${ }^{42}$ Budući da su se nalazili na licu mesta, bez obzira na to što su od strane vladinih predstavnika pre 27. marta dobijali samo ograničene informacije i suštinski bili upućeni na kontakte s predstavnicima opozicije, sovjetski civilni i vojni diplomatski predstavnici u Beogradu su realnije procenjivali stanje u Jugoslaviji i raspoloženje kako vlasti, tako i građanstva prema nemačkim zahtevima i mogućoj sovjetskoj alternativi. Za razliku od svojih kolega u Moskvi i zemljama neposrednog jugoslovenskog okruženja, oni su pravili jasnu distinkciju između sveukupnog jugoslovenskog javnog mnjenja i stavova srpske sredine. Gajeći osećaj za unutrašnje posebnosti, pa i podvojenosti unutar jugoslovenskog društva, jasno su markirali ulogu srpskog faktora u vojnom puču, suprotstavljanju Nemačkoj i približavanju Sovjetskom Savezu.

$$
* * *
$$

Sovjetska diplomatija je u svetlu jačanja nemačkog uticaja na Balkanu pomno pratila dešavanja u Jugoslaviji. Prevrat od 26/27. marta 1941. dočekala je sa simpatijama, ali u skladu s politikom neizazivanja nemačkih reakcija nije pružila otvorenu podršku novoj vladi u Beogradu. Godine nepostojanja regularnih diplomatskih odnosa i odsustva sovjetske diplomatske misije ostavile su traga na funkcionisanje sovjetske diplomatske misije koja je u Beograd stigla svega nekoliko meseci pre 27-martovskih događaja. Nepostojanje čvrstih veza u jugoslovenskom državnom aparatu, predrasude i rezerve koje su gajene prema delovanju sovjetskih diplomatskih službenika u Beogradu, restriktivan pristup zvaničnim informacijama, kao i podozrenje prema stvarnim sovjetskim namerama učinili su da informacije kojima je sovjetska diplomatska služba u Beogradu raspolagala budu ograničenog karaktera. Nedostatak kvalitetnih informacija, ali i često nerazumevanje i nepoznavanje beogradske sredine ostavili su

\footnotetext{
${ }^{39}$ AVPRF, 6, o.3, d. 371, p. 27, 1. 24.

${ }^{40}$ AVPRF, 6, o.3, d. 371, p. 27, 1. 20.

${ }^{41}$ AVPRF, 6, o.3, d. 371, p. 27, 1. 2.

${ }^{42}$ AVPRF, 6, o.3, d. 371, p. 27, 1. 21.
} 
svoj pečat ne samo u oskudnosti informacija, već i u načinu na koji su tumačeni glavni politički procesi, pojave i događaji u političkom životu jugoslovenske kraljevine. Manjak pouzdanih informacija ,nadomešten“ je u praksi šablonskim ideološkim tumačenjima, što je često bio put ka stvaranju pogrešne slike o dešavanjima u Jugoslaviji. Iako je sovjetsko poslanstvo u Beogradu bilo suočeno s nizom objektivnih teškoća i uskraćeno za mnoge važne informacije, analize dešavanja u Jugoslaviji proistekle iz pera otpravnika poslova Lebedeva i vojnog atašea generala Samohina su u pogledu razmatranja unutrašnjih problema daleko prevazilazile po svom kvalitetu tumačenja nastala u centralnom aparatu sovjetske diplomatije u Moskvi. 


\section{REFERENCE}

- Bjelajac, Mile. „Pokušaj strateškog oslonca na SSSR 1939-1941“. Vojnoistorijski glasnik, 1-2, (2006), 41-66.

- Cvetković, Slavoljub. „Jugoslovensko-sovjetski pregovori 1941. o zaključenju ugovora o prijateljstvu i nenapadanju“. Vojnoistorijski glasnik, 1, (1991), $11-26$.

- Gavrilov, Viktor. Voennaya razvedka informiruet. Dokumenty Razvedupravleniya Krasnoj armii: yanvar' 1939-iyun' 1941. Moskva: Demokratiya, 2009.

- Gibianskij, Leonid Ya. „Sovetskij Soyuz i serbskij voennyj perevorot 27 marta 1941 goda: istoricheskaya dejstvitel'nost', mify, zagadki“. U: Iz istorii Serbii i russko-serbskix svyazej. 1812-1912-2012. Urednik Konstantin V. Nikiforov, 210-264. Moskva: InSlav RAN, 2014.

- Hoptner, Jacob. Jugoslavija u krizi 1934-1941. Rijeka: Otokar Keršovani, 1973.

- Knežević, Živan. 27. mart 1941. New York: Ž. L. Knežević, 1979.

- Milošević, Miladin. „Uspostavljanje diplomatskih odnosa između Kraljevine Jugoslavije i SSSR-a 1940. godine“. Istorijski zapisi, 3-4, (2002), 99-124.

- Novikov, Nikolaj. Vospominaniya diplomata. Moskva: IPL, 1989.

- Pavlović, Momčilo, urednik. 27. mart 1941. Sedamdeset godina kasnije. Zbornik radova. Beograd: Institut za savremenu istoriju, 2012.

- Petranović Branko, i Nikola Žutić. 27. mart 1941. Tematska zbirka dokumenata. Beograd: Nicom, 1990.

- Petranović, Branko. Srbija u Drugom svetskom ratu 1939-1941. Beograd: Vojnoizdavački i novinski centar, 1992.

- Sudoplatov, Pavel. Razvedka i Kreml': Zapiska nezhelatel'nogo svidetelya. Moskva: Olma press, 1996.

- Volkov K. Vladimir, i Leonid Ya. Gibianskij. Vostochnaya Evropa mezhdu Gitlerom i Stalinym 1939-1941. Moskva: Indrik, 1999.

- Zelenin, Vladimir, urednik. Sovetsko-yugoslavskie otnosheniya 1917-1941. Moskva: Nauka, 1992.

- Životić, Aleksandar. Jugoslovensko-sovjetski odnosi 1939-1941. Beograd: Filip Višnjić, 2016.

- Životić, Aleksandar. „Pokušaj uspostavljanja diplomatskih odnosa između Jugoslavije i Sovjetskog Saveza (1923-1927)“. U: Rusija/SSSR i državnost Srbije/Jugoslavije. Urednici Srđan Rudić i Konstantin V. Nikiforov, 229-322. Beograd: Istorijski institut, 2018. 
ALEKSANDAR ŽIVOTIĆ, PhD, Associate Professor

Faculty of Philosophy, University of Belgrade

Belgrade, Republic of Serbia

aleksandar.zivotic@f.bg.ac.rs

\section{SOVIET DIPLOMACY ON THE MARCH 26/27, 1941 EVENTS IN YUGOSLAVIA}

\section{Summary}

Soviet diplomacy interpreted Yugoslavia's position as a result of the process that happened from its origin and place and role in the new system of international relations guided by France and Great Britain. They thought - after the fall of France, Italy's entry into the war, and the growing German pressure on the Balkans - that Yugoslavia had found itself in a kind of foreign policy isolation and was forced to sign a series of unfavorable economic agreements with Germany. According to Soviet sources, the German influence was also manifested in the political sphere by the actions of prominently politically motivated politicians and journalists, as well as "numerous German agents." They viewed the policy carried out by the previous government as a "concession" policy, and its decision to join the Tripartite Pact as the result of German pressure and the inability to provide resolute resistance to German demands. The new government was seen as a conglomeration of representatives of various political ideas, still dominated by the supporters of the new course of Yugoslav foreign policy in relation to the members of the shadow government that found themselves in the new one. Soviet diplomacy worried about the position of Croatian politicians in the new government, since the leadership of the Croatian Peasant Party stood firmly in the position of joining Yugoslavia in the Tripartite Pact. The Soviets encouraged the measures taken by the Yugoslav Government to arrest politicians and journalists, remove pro-German officers from important command positions and mobilize the military. Regarding the further development of events, Soviet diplomacy estimated that the United Kingdom would strive to exploit the uprising in Belgrade in order to form a Balkan front, which would include Yugoslavia, Greece, and possibly Turkey with British support.

KEYWORDS: Yugoslavia, USSR, Germany, Diplomacy, March 27, Government, Military Coup 